\title{
How does the added fat source affect sensory quality of sheep and goat pâtés?
}

\author{
Sandra Rodrigues ${ }^{1}$ (iD) Samanta Almeida ${ }^{2}$ Etelvina Pereira ${ }^{2}$ Alfredo Teixeira $^{1^{*}}$ (iD
}

\begin{abstract}
${ }^{1}$ Centro de Investigação de Montanha (CIMO), Instituto Politécnico de Bragança (IPB), Campus Santa Apolónia, 5300-253, Bragança, Portugal. E-mail: teixeira@ipb.pt. *Corresponding author.
\end{abstract}

${ }^{2}$ Instituto Politécnico de Bragança (IPB), Escola Superior Agrária, Campus Santa Apolónia, Bragança, Portugal.

\begin{abstract}
Sensory quality of sheep and goat pâtés with different sources and percentage of fat (10\% or 30\%, and pork belly or olive oil) were evaluated. A trained taste panel performed sensory analysis and consumers were consulted to perceive their preferences. Generalised Procrustes Analysis was used to test the differences found by panellists. Panellists were able to find sensory differences between sheep and goat pâtés, and also fat percentages. Goat pâtés had higher values of juiciness and sheep pâtés had higher values of taste intensity. Ten percent pork belly fat pâtés had the highest values of colour and cohesiveness attributes and also aroma intensity, while $30 \%$ olive oil pâtés had the highest values of texture attributes, except cohesiveness. Although, differences between pâtés were found by panellists, consumers had no particular preference for one of them.
\end{abstract}

Key words: pâté, goats and sheep meat, pork fat, olive oil, sensory analysis.

Como a fonte de gordura adicionada afeta a qualidade sensorial de patês de ovinos e caprinos?

RESUMO: Avaliou-se a qualidade sensorial de patês de carne de ovelhas e cabras com diferentes fontes e percentagem de gordura (10\% ou $30 \%$, e barriga de porco ou azeite). Um painel de provadores treinado realizou análise sensorial e foram consultados consumidores para perceber as suas preferências. A análise generalizada de Procrustes foi usada para testar as diferenças encontradas pelos provadores. Os painelistas conseguiram encontrar diferenças sensoriais entre os patês de ovelhas e cabras e também percentagens de gordura. Os patês de cabra apresentaram valores mais elevados de suculência e os patês de ovelhas apresentaram maiores valores de intensidade de sabor. Patês com $10 \%$ de gordura de barriga de porco tiveram os maiores valores para os atributos de cor e coesividade e também intensidade de aroma, enquanto patês com $30 \%$ de azeite apresentaram os maiores valores para os atributos de textura, exceto coesividade. Embora as diferenças entre os patês tenham sido encontradas pelos membros do painel, os consumidores não mostraram uma preferência particular por um deles. Palavras-chave: patê, carne de ovinos e caprinos, gordura de barriga de porco, azeite de oliva, análise sensorial.

\section{INTRODUCTION}

Sheep and goats' meat has a seasonal demand, particularly associated to festive holidays, like Christmas, Easter and summer religious holidays. Preferences are for younger and lighter animals (RODRIGUES \& TEIXEIRA, 2010). Availability of live animals, particularly those with Protected Designation of Origin (PDO) or Protected Geographical Indication (PGI) quality brands can affect the value of goat and sheep meat according to demand versus supply. Demand is not always accompanied by supply, and unconsumed animals end up exceeding the age and weight defined by the specifications of quality brands and preferred by consumers, losing economic value. One way to get around this situation can be through the processing of meats, transforming them into new products. In many countries, mainly from the Mediterranean area and Middle East, Africa or South America, goats and sheep meat is processed with salts, smoke or air-drying (WEBB et al., 2005). In Spain "Cecina" (STERLING \& JONES, 2000; HIERRO et al., 2004), in Italy "violino di capra" (FRATIANNI et al., 2008) or in Brazil "Buchada" or fermented goat sausages (NASSU et al., 2003) are examples of processed products that use goat or sheep meat and also viscera (liver, heart, lungs, kidney), intestines and blood. BOVOLENTA et al. (2008) studied a fermented sausage using sheep meat, and LEITE et al. (2015) 
studied a fresh sausage made with sheep and goats' meat. GUERRA et al. (2011) evaluated a goat mortadella prepared with different levels of fat and goat meat from discarded animals, and DALMÁS et al. (2011) and AMARAL et al. (2013) studied a goat pâté, prepared using variety meat (spent goat meat, goat liver and blood). Pâté is a popular processed product, made from fresh livers and the most famous is the Pâté de fois gras with livers of fatty geese or duck. However, other popular pâtés are commonly made with chicken and pork livers. The use of other kind of meat as sheep and goat are not so popular. This type of product was considered in a project aiming to add value to sheep and goat's meat from animals out of age and weight defined by PDO or PGI specifications. Physical and chemical analysis were performed but not presented in this paper. When a new product is produced it is of fundamental importance to know its sensorial characteristics and to see if it will be accepted by consumers. Thus, the aim of this study was to analyse the effect of fat source (olive oil or pork belly) on the sensory quality of sheep or goat meat pâtés and identify preferences by consumers.

\section{MATERIALS AND METHODS}

The data analysed are an integrated part of a project between a research centre (Carcass and Meat Quality and technology Laboratory of Agriculture School of Polytechnic Institute of Bragança, Portugal), two Portuguese breeder associations (ANCRAS - National Breed Producers Association of Serrana Goat and ACOB - National Breed Producers Association of Bragançana Sheep) and a meat manufacturing industry and Bísaro breed producer (Bìsaro Salsicharia Tradicional). The objective was to develop new meat products to give added value to animals and carcass meat trimmings with low commercial value.

\section{Pâté manufacturing process and sampling}

Meat trimmings of carcasses used to manufacture the pâtés were from local breeds Churra Galega Bragançana ewes and Serrana goats aged between 5 and 7 years old, with an average carcass weight of $20 \mathrm{~kg}$. The pork belly is from females of local breed Bísaro weighing between 110 and $130 \mathrm{~kg}$ body weight. Animals were slaughtered according to standard procedures in the Municipal slaughterhouse of Bragança, Portugal. Carcasses were refrigerated for $24 \mathrm{~h}$, at $4{ }^{\circ} \mathrm{C}$, cut into pieces and then the ones needed were conveniently transported in a refrigerated truck to the facilities to produce the pâtés. Two lots of eight types of pâtés were manufactured, one at the Laboratory of Carcass and Meat Quality of Agriculture School of Polytechnic Institute of Bragança and the other at the meat manufacturing industry Bísaro Salsicharia. Pâtés were made mincing and mixing meat (sheep or goat), previously boiled (60 minutes) with different amounts of pork belly/ olive oil and other ingredients (water, milk, and mix) depending on the batch (Table 1). Three hundred $\mathrm{ml}$ capacity glass beakers were filled with the mixture and sealed with a vacuum cap and heated for 30 minutes in a water bath in an oven at $170{ }^{\circ} \mathrm{C}$. Beakers were refrigerated at $4{ }^{\circ} \mathrm{C}$ until analysed.

Two replicas of each of the eight types of pâtés: GPB1 (Goat $+10 \%$ pork belly); GPB3 (Goat $+30 \%$ pork belly); GOO1 (Goat $+10 \%$ olive oil); GOO3 (Goat $+30 \%$ olive oil); SPB1 (Sheep $+10 \%$

Table 1 - Pâtés formulations.

\begin{tabular}{lcccccccc}
\hline Ingredients & GOO1 & GOO3 & GPB1 & GPB3 & SOO1 & SOO3 & SPB1 & SPB3 \\
\hline Goat meat $(\mathrm{g})$ & 2180 & 1580 & 4500 & 3500 & 0 & 1580 & 0 \\
\hline Sheep meat $(\mathrm{g})$ & 0 & & 0 & 0 & 2180 & 0 & 4500 & 3500 \\
\hline Pork belly (g) & 0 & & 500 & 1500 & 0 & 500 & 1500 & 375 \\
Mix-088 Patê Bueton $(\mathrm{g})^{\mathrm{a}}$ & 164 & 164 & 375 & 375 & 164 & 164 & 375 & 375 \\
Cooking milk (ml) & 200 & 200 & 500 & 500 & 200 & 200 & 500 & 500 \\
Water (ml) & 100 & 100 & 500 & 500 & 100 & 100 & 500 & 500 \\
\hline Olive oil (ml) & 300 & 900 & 0 & 0 & 300 & 900 & 0 \\
Total & 2944 & 2944 & 6375 & 6375 & 2944 & 2944 & 6375 & 6375 \\
\hline
\end{tabular}

${ }^{a}$ Commercial designation of the mixture used for seasoning the pâtés.

${ }^{\mathrm{b}}$ Cooking milk: UHT milk from a trademark was used. 
pork belly); SPB3 (Sheep $+30 \%$ pork belly); SOO1 (Sheep $+10 \%$ olive oil) and SOO3 (Sheep $+30 \%$ olive oil) were manufactured.

\section{Sensory analysis}

The pâtés sensory analysis was performed by 8 trained panellists, following the Portuguese Standard (NP-ISO-8586-1). The panel members make meat products sensory evaluations for more than 10 years and are trained to scale use. Pâtés evaluation training consisted of 4 specific sessions, in which the product was presented, evaluated, and discussed to establish and define sensory attributes to be assessed. In each training session at least 3 different samples of the pâtes to be evaluated were presented to the panellists, first they were free to give their own impressions using their senses, next the terms used by them were discussed in a group session, to normalise the different terms (sensory feelings), then sensory attributes were defined and finally trained using the same scale as in evaluation sessions. Each sample was then evaluated for appearance (pâté colour, from rose to brown, cohesiveness, appearance of loose or bonded particles, from little to very cohesive, homogeneity or uniformity of the mixture, from little to very homogeneous), aroma intensity (global intensity of aroma associated to pâté, from little to very intense), taste intensity (global intensity of taste associated to pâté, from little to very intense), and texture (cohesiveness, bonding feeling in the mouth pressing the tongue against the palate of the pâté paste, from little to very cohesive, adhesiveness, adherence of the sample, without chewing, to the palate after being pressed with the tongue, little to very adhesive, fatness, sensation of fat particles in the mouth, little to very fat, juiciness, impression of lubrication of the sample during chewing, little to very juicy) using Quantitative Descriptive method (NORMA PORTUGUESA, 2001). Eight samples were evaluated in each of 7 weekly sessions. A structured but unnumbered scale of $10 \mathrm{~cm}$, with the extremes representing either the minimum (no sensation) or maximum (extremely intense sensation) was used.

Samples were removed from the refrigerator approximately 30 minutes before preparation. About 15 minutes before the evaluation, samples were divided in small portions of $10 \mathrm{~g}$ and packed in aluminium sheets. Samples were random coded using 3 digits numbers to prevent influences. Panellists evaluated all samples by the order established by the panel leader in individual booths. Between samples panellists rinsed their mouths with plain water and apple (Golden variety) to prevent influences from the previous sample. All sessions were performed in the Laboratory of Sensory Analysis of the Agriculture School of Polytechnic Institute of Bragança under controlled environment conditions.

Aiming to evaluate Pâté preferences, a consumer's panel was constituted. With no training, based on their experience, they had to indicate how much they appreciated the different pâtés. The consumers' panel was constituted by teachers, staff, and students of the IPB ageing between 18 and 56 years old. With an average of 27 years old, most consumers were young people. Therefore, giving the opportunity to study the preferences of this population group, supposedly more reactionary to consume goat and sheep meat or based products. In the study $44 \%$ were females and $56 \%$ were males. For each sample, consumers evaluated the overall acceptability, using a $10 \mathrm{~cm}$ scale (from $0 \mathrm{~cm}$ "do not like" to $10 \mathrm{~cm}$ "like very much").

Samples were removed from the refrigerator 30 minutes before preparation, and about 15 minutes before the evaluation samples were prepared. To simulate real consumption conditions, samples were served on little toasts, gently involved with aluminium sheets. These evaluation sessions were made in controlled environment in the Superior Agriculture School bar, guaranteeing that consuming conditions were equal to all consumers. In each of 3 sessions, 4 samples, conveniently encoded, were evaluated by 25 individuals.

\section{Statistical analysis}

Data from the taste panel sensory evaluation were analysed by Generalized Procrustes Analysis (GPA). GPA is a powerful multivariate technique extensively used in sensory evaluation. The analysis used translation, rotation, and isotropic scaling to minimize differences among panellists (GOWER 1975), identified agreement between them, and summarized the sets of 3-dimensional data (samples, characteristics, and assessors). The data matrices of 8 (pates samples) by 9 (sensory attributes) for the 8 assessors (configurations) were matched to find a consensus using the XLSTAT version 2016 a Microsoft Office Excel software add in (Addinsoft, New York, NY). Results corresponded to the average evaluation established by each panellist for each pâté and the respective sensory attribute. Global appreciation for each pâté was compared by analysis of variance (One-way ANOVA), with the same software. 


\section{RESULTS AND DISCUSSION}

\section{Sensory analysis}

Nine attributes (colour, cohesiveness as appearance, homogeneity, aroma intensity, taste intensity, cohesiveness as texture, adhesively, fatness and juiciness) were assessed by panellists to describe differences among pâté samples. The training period allowed assessors to uniform the evaluation methodology. However, no training can eliminate variation among panellists, and panellist 7 had the greatest residual (Table 2). In sensory analysis some panellists have the tendency to use a wide range of the given scale, whereas others focus on a narrower part of the scale. Scaling factors in table 2 show that panellists $3,4,5$, and 7 tended to use a wider scale range because they presented scaling factors greater than 1. Residuals by object varied between 6.15 for GOO1, the most consensual pâté, and 12.99 for SOO1, the least consensual.

To minimize differences between assessors, GPA was used to find a consensus (Figure 1). The first 2 principal axes of the consensus configuration accounted for $79.49 \%$ of the total variation among the samples. The F3 factor explains $7.59 \%$ more of the remaining $11 \%$ of the total variation. Previous research had higher values of total variability explained by the 2 first dimensions, as 93\% (RODRIGUES \& TEIXEIRA, 2009) in goat fresh meat, 88\% (PAULOS et al. 2015) in sheep and goat meat fresh sausages, but also smaller as $73 \%$ (RODRIGUES \& TEIXEIRA, 2013) in sheep fresh meat.

The means and standard errors of sensory traits observed by panellists for all pâtés are given in table 3 . In the same table correlations between sensory attributes and the factors 1, 2 and 3 (F1, F2 and F3) are presented. Appearance traits (colour and cohesiveness), also aroma intensity is highly and negatively correlated with F1. Adhesiveness is highly and positively correlated with F1. So, F1 can be considered as representing appearance and aroma. Cohesiveness as texture is highly and negatively correlated with F2. So, F2 can represent cohesiveness. Finally, appearance homogeneity, and taste intensity are highly and negatively correlated with F3, and fatness and juiciness are highly and positively correlated with F3. Since fatness can give a moisture sensation, F3 can represent juiciness.

Figure 1 shows that panellists could differentiate between pâtés' fat sources, independently of species' meat (goat or sheep) as the pâtés appear well separated in the conjoint representation. Following the order from the most negative part of $F 1$ to the most positive, the first pâtés to appear are GPB1 and SPB1, characterized by its higher colour values (browner) given that the vector representing this sensory trait directs towards them; then SOO1 and GOO1, then SPB3 and GPB3, and finally SOO3 and GOO3. So, $10 \%$ pork belly fat pâtés had highest values of colour and cohesiveness appearance attributes, and aroma intensity. Colour differences may be due to the pâté's different composition, not only species but fat type and percentage. Almost 2 decades ago, many authors cited by HUGHES et al. (1998) referred the fat influence on meat products colour. Colour differences were also observed by VIANA et al. (2005) in a study about sensory quality of ham pâté containing bovine globin and plasma as fat replacers. Also, DUTRA et al. (2013) referred the darker colour when sheep meat substituted pork meat in a study of the technological

Table 2 - Residual variance, scaling factors, and percentage variation explained by the first 2 principal components for each assessor for sheep or goat pâtés sensory analysis.

\begin{tabular}{|c|c|c|c|c|c|}
\hline Panelist & Residuals & Scaling factors & F1 \% & $\mathrm{F} 2 \%$ & F3 \% \\
\hline 1 & 4.6 & 0.88 & 73.6 & 6.0 & 9.6 \\
\hline 2 & 10.9 & 0.72 & 61.2 & 20.8 & 9.5 \\
\hline 3 & 11.3 & 1.24 & 55.6 & 13.8 & 10.0 \\
\hline 4 & 10.2 & 1.21 & 48.0 & 13.1 & 16.2 \\
\hline 5 & 7.6 & 1.25 & 70.9 & 10.9 & 5.8 \\
\hline 6 & 5.9 & 0.98 & 81.1 & 5.2 & 4.1 \\
\hline 7 & 15.9 & 1.61 & 27.9 & 35.7 & 10.2 \\
\hline 8 & 7.5 & 0.89 & 85.3 & 4.0 & 2.8 \\
\hline
\end{tabular}

F1=1st principal component of Generalized Procrustes Analysis (GPA); F2=2nd principal component of GPA; F3=3rd principal component of GPA. 

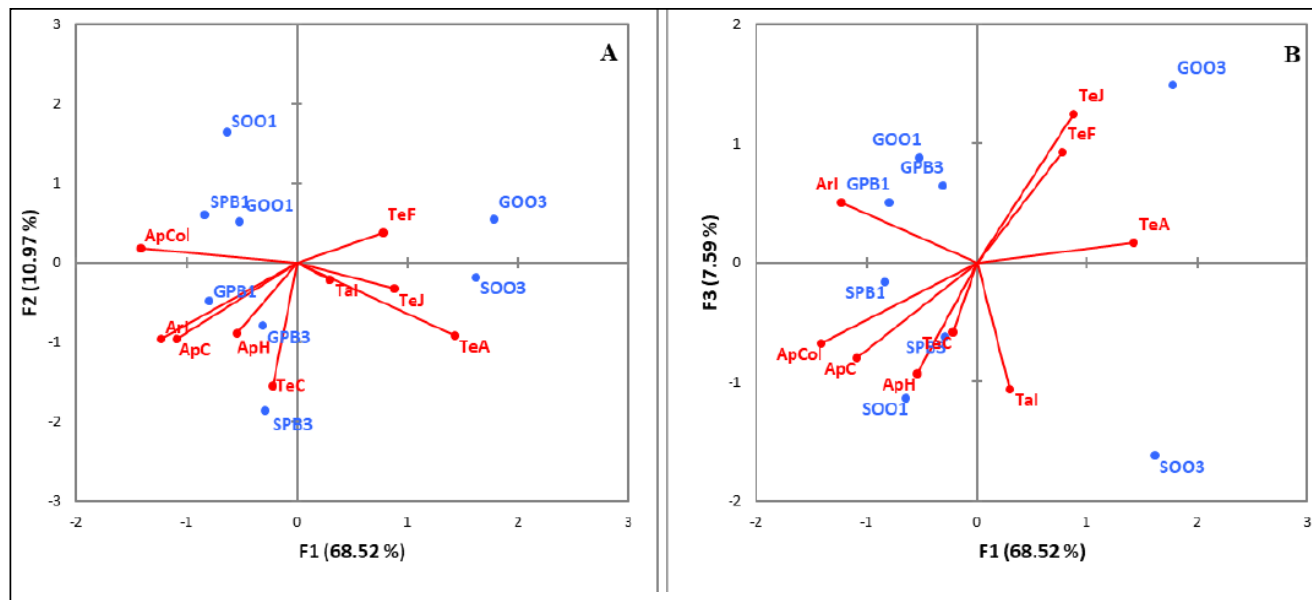

Figure 1 - Consensus configuration: joint representation of correlation between sensory traits and F1 and F2 (A) and F1 and F3 (B) and pâtés coordinates for sensory analysis. F1 = first principal component of generalized Procrustes analysis (GPA); F2 = second principal component of GPA; F3 = third principal component of GPA.

GPB1 (Goat $+10 \%$ pork belly); GPB3 (Goat $+30 \%$ pork belly); GOO1 (Goat $+10 \%$ olive oil); GOO2 (Goat $+30 \%$ olive oil). SPB1 (Sheep $+10 \%$ pork belly); SPB3 (Sheep $+30 \%$ pork belly); SOO1 (Sheep $+10 \%$ olive oil); SOO2 (Sheep $+30 \%$ olive oil).

Specie (sheep, goat); Fat (pork belly, olive oil); Sp x F (interaction specie x fat source). ApCol: color, ApC: cohesiveness, ApH: homogeneity, ArI: aroma intensity, TaI: taste intensity, TeC: cohesiveness, TeA: adhesiveness, TeF: fatness, TeJ: juiciness.

and quality characteristics of cooked ham-type pâté elaborated with sheep meat, associating it to the heme pigments.

In the most positive part of $\mathrm{F} 1$ are $\mathrm{GOO} 3$ and SOO3 with the adhesiveness, fatness and juiciness highest values. Pâtés with $30 \%$ pork belly were the most cohesive when evaluated in the mouth.

HUGHES et al. (1998) also referred the influence of fat in texture, taste and flavour profiles of food. Contrarily to our findings, no differences were reported by VIANA et al. (2005) for taste, aroma and consistency when using fat replacers. These authors also evaluated pâtés instrumental texture and concluded that fat replacement had a significant effect on hardness, cohesiveness, and tackiness but not on adhesiveness, or elasticity. Furthermore, differences on instrumental texture were reported by ESTÉVEZ et al. (2005) testing fat reduction to produce healthier pâtés and by LORENZO and PATEIRO (2013) when foal liver pâté fat percentage was reduced. Fat reduction increased hardness, chewiness, gumminess, cohesiveness.
A conjoint representation of F1 and F3 (Figure 1B) shows a clear separation between sheep and goat pâtés. Goat pâtés, particularly GOO3, positioned in the positive part of axis representing F3, were considered as producing more fat sensation in the mouth and were juicier than sheep pates. Both sensory attributes can be related since fat can give a sensation of moisture in the mouth. This result contradicts the findings of PAULOS et al. (2015) since they reported that sheep fresh sausages were juicier than goat fresh sausages. Sheep pâtés had more homogeneous appearance and presented more intense taste.

No significant $(\mathrm{P}>0.05)$ differences were reported among the various pâtés when consumers were consulted. Means ranged between $6.5 \pm 0.2$ (mean \pm standard error) for SOO1 and $7.5 \pm 0.4$ for GPB3. The intermediate values were $6.9 \pm 0.4$ (SPB3), $6.9 \pm 0.4$ (SPB1), $7.0 \pm 0.4$ (SOO3), $7.1 \pm 0.4$ (GPB1), $7.2 \pm 0.4$ (GOO3), $7.3 \pm 0.2$ (GOO1). DUTRA et al. (2013) also reported no significant preferences for the 5 different pâtés elaborated with sheep meat. 
Table 3 - Correlation between sensory traits and factors produced in generalized Procrustes analysis (GPA) for the pâtés sensory analysis and sensory scores (means \pm standard error) assessed by panellists.

\begin{tabular}{lccccccccccccc}
\hline & - & & & & & & & & \\
\hline Sensory trait & F1 & F2 & F3 & GPB1 & GPB3 & GOO1 & GOO3 & SPB1 & SPB3 & SOO1 & SOO3 \\
ApCol & -0.81 & 0.11 & -0.39 & $6.7 \pm 0.24$ & $6.1 \pm 0.30$ & $6.6 \pm 0.37$ & $5.3 \pm 0.23$ & $6.6 \pm 0.24$ & $6.2 \pm 0.29$ & $6.5 \pm 0.36$ & $6.1 \pm 0.23$ \\
ApC & -0.63 & -0.55 & -0.46 & $5.8 \pm 0.25$ & $5.4 \pm 0.25$ & $5.3 \pm 0.34$ & $4.2 \pm 0.27$ & $5.7 \pm 0.25$ & $5.8 \pm 0.22$ & $5.1 \pm 0.36$ & $5.4 \pm 0.32$ \\
ApH & -0.32 & -0.51 & -0.53 & $5.8 \pm 0.31$ & $5.0 \pm 0.27$ & $5.3 \pm 0.34$ & $4.5 \pm 0.24$ & $5.6 \pm 0.27$ & $5.6 \pm 0.27$ & $5.0 \pm 0.34$ & $5.8 \pm 0.26$ \\
ArI & -0.71 & -0.55 & 0.29 & $6.0 \pm 0.25$ & $5.9 \pm 0.17$ & $5.8 \pm 0.30$ & $5.6 \pm 0.19$ & $5.8 \pm 0.22$ & $5.9 \pm 0.21$ & $5.6 \pm 0.31$ & $5.7 \pm 0.30$ \\
TaI & 0.17 & -0.12 & -0.61 & $5.9 \pm 0.26$ & $6.2 \pm 0.20$ & $6.1 \pm 0.32$ & $5.9 \pm 1.98$ & $5.9 \pm 0.24$ & $6.1 \pm 0.18$ & $6.1 \pm 0.29$ & $6.3 \pm 0.21$ \\
TeC & -0.12 & -0.89 & -0.34 & $6.1 \pm 0.24$ & $5.6 \pm 0.25$ & $5.1 \pm 0.25$ & $5.2 \pm 0.22$ & $5.7 \pm 0.25$ & $6.0 \pm 0.22$ & $5.1 \pm 0.29$ & $5.7 \pm 0.20$ \\
TeA & 0.82 & -0.53 & 0.10 & $4.2 \pm 0.32$ & $4.7 \pm 0.31$ & $4.5 \pm 0.43$ & $5.5 \pm 0.35$ & $3.9 \pm 0.28$ & $5.1 \pm 0.30$ & $4.1 \pm 0.36$ & $5.4 \pm 0.40$ \\
TeF & 0.45 & 0.22 & 0.54 & $3.0 \pm 0.25$ & $3.2 \pm 0.28$ & $3.4 \pm 0.29$ & $3.4 \pm 0.41$ & $2.7 \pm 0.24$ & $2.8 \pm 0.23$ & $2.8 \pm 0.32$ & $3.3 \pm 0.42$ \\
TeJ & 0.50 & -0.19 & 0.72 & $6.0 \pm 0.30$ & $6.0 \pm 0.30$ & $5.8 \pm 0.38$ & $6.3 \pm 0.21$ & $5.4 \pm 0.30$ & $5.5 \pm 0.31$ & $5.3 \pm 0.40$ & $5.9 \pm 0.26$ \\
\hline
\end{tabular}

${ }^{1} \mathrm{~F} 1=1$ st principal component of Generalized Procrustes Analysis (GPA); F2 = 2nd principal component of GPA; F3 = 3rd principal component of GPA.

${ }^{2}$ GPB1 (Goat $+10 \%$ pork belly); GPB3 (Goat $+30 \%$ pork belly); GOO1 (Goat $+10 \%$ olive oil); GOO2 (Goat $+30 \%$ olive oil). SPB1 (Sheep + 10\% pork belly); SPB3 (Sheep + 30\% pork belly); SOO1 (Sheep + 10\% olive oil); SOO2 (Sheep + 30\% olive oil). Specie (sheep, goat); Fat (pork belly, olive oil); Sp x F (interaction specie $\mathrm{x}$ fat source).

ApCol: color, ApC: cohesiveness, ApH: homogeneity, ArI: aroma intensity, TaI: taste intensity, TeC: cohesiveness, TeA: adhesiveness, TeF: fatness, TeJ: juiciness.

Consumers' age and gender had no significant influence on the pâté's preferences. Not all age groups evaluated the different pâtés. However, differences were reported between people in their 30 's and younger one. Globally, younger people gave the pâtés significantly $(\mathrm{p}=0.0012)$ higher scores than 30 's (7.3 vs 5.2$)$.

\section{CONCLUSION}

Panellists were able to find sensory differences between sheep and goat pâtés, and also fat percentages. Goat pâtés had higher values of juiciness and sheep pâtés had higher values of taste intensity. Ten percent pork belly fat pâtés had the highest values of colour and cohesiveness attributes and also aroma intensity, while $30 \%$ olive oil pâtés had the highest values of texture attributes, except cohesiveness. Although, differences between pâtés were reported by panellists, consumers had no particular preference for them.

\section{ACKNOWLEDGEMENTS}

Work included in the Portuguese PRODER research Project number 020260013013 "New goat and sheep processed meat products" BISOVICAP - Processing meat from pigs, sheep and goats, to produce new products. Ham and pâté, Project PROTEC, SI I\&DT - Projects in Co-Promotion, $\mathrm{n}^{\circ}$ 21511. The authors are grateful to the Laboratory of Carcass and Meat Quality and to the Laboratory of Sensory Analysis of Agriculture School of Polytechnic Institute of Bragança 'Cantinho do Alfredo'. The authors are members of the MARCARNE network, funded by CYTED (ref. 116RT0503).

\section{DECLARATION OF CONFLICT OF INTERESTS}

The authors declare no conflict of interest. The founding sponsors had no role in the design of the study; in the collection, analyses, or interpretation of data; in the writing of the manuscript, and in the decision to publish the results.

\section{AUTHORS' CONTRIBUTIONS}

The authors contributed equally to the manuscript.

\section{REFERENCES}

AMARAL, D.S. et al. Chemical and sensory quality of sheep liver pâté prepared with "variety meat". Ciências Agrárias, Londrina, v. 34, n.4, p. 1741-1752, 2013. Available from <https://www.

Ciência Rural, v.49, n.5, 2019. 
redalyc.org/html/4457/445744122024/>. Accessed: Nov. 10, 2018. doi: $10.5433 / 1679-0359.2013 \mathrm{v} 34 \mathrm{n} 4 \mathrm{p} 1741$.

BOVOLENTA, S. et al. Effect of pork lard content on the chemical, microbiological and sensory properties of a typical fermented meat product (Pitina) obtained from Alpagota sheep. Meat Science, v. 80, p. 771-779, 2008. Available from: $<$ https://www.sciencedirect. com/science/article/pii/S0309174008000909\#!>. Accessed: Nov. 10, 2018. doi: 10.1016/j.meatsci.2008.03.021.

DALMÁS, P.S. et al. Development of goat pâté prepared with "variety meat". Small Ruminant Research, v.98, p.6-50, 2011. Available from: <https://www.sciencedirect.com/science/ article/pii/S0921448811000915>. Accessed: Nov. 10, 2018. doi: 10.1016/j.smallrumres.2011.03.016.

DUTRA, M.P. et al. Technological and quality characteristics of cooked ham-type pâté elaborated with sheep meat. Small Ruminant Research, v.115, p.56- 61, 2013. Available from: $<$ https://www. sciencedirect.com/science/article/pii/S0921448813002848>. Accessed: Dec. 20, 2018. doi: 10.1016/j.smallrumres.2013.08.007.

ESTÉVEZ, M. et al. Physicochemical properties and oxidative stability of liver pâtés as affected by bat content. Food Chemistry, v.92, p.449-457, 2005. Available from: $<$ https://www.sciencedirect. com/science/article/pii/S0308814604006211>. Accessed: Nov. 12, 2018. doi: 10.1016/j.foodchem.2004.08.014.

FRATIANNI, F. et al. Micro-electrophoretic study of sarcoplasmic fraction in the dry-cured goat raw ham. The Open Food Science Journal, v.2, p.89-94, 2008. Available from: <https:// benthamopen.com/ABSTRACT/TOFSJ-2-89>. Accessed: Dec. 20, 2018. doi: 10.2174/1874256400802010089.

GOWER, J.C. Generalized procrustes analysis. Psychometrika, v.40, n.1, p.33-51, 1975. Available from: <https://link.springer. com/article/10.1007/BF02291478>. Accessed: Nov. 12, 2018. doi: 10.1007/BF02291478.

GUERRA, I.C.D. et al. Evaluation of goat mortadella prepared with different levels of fat and goat meat from discarded animals. Small Ruminant Research, v.98, p.59-63, 2011. Available from: <https:// www.sciencedirect.com/science/article/pii/S0921448811000940>. Accessed: Dec. 20, 2018. doi: 0.1016/j.smallrumres.2011.03.019.

HIERRO, E. et al. Headspace volatile compounds from salted and occasionally smoked dried meats (cecinas) as affected by animal species. Food Chemistry, v.85, n.4, p.649-657, 2004. Available from: <https:/www.sciencedirect.com/science/article/pii/ S0308814603003947>. Accessed: Nov. 12, 2018. doi: 10.1016/j. foodchem.2003.07.001.

HUGHES, E. et al. Effects of fat level, tapioca starch and whey protein on frankfurters formulated with $5 \%$ and $12 \%$ fat. Meat Science, v.48, n.1/2, p.169-180, 1998. Available from: <https:// www.sciencedirect.com/science/article/pii/S0309174097000879>. Accessed: Dec. 20, 2018. <https://doi.org/10.1016/S03091740(97)00087-9>

LEITE, A. et al. Physicochemical properties, fatty acid profile and sensory characteristics of sheep and goat meat sausages manufactured with different pork fat levels. Meat Science, v.105, p.114-120, 2015. Available from: <https:/www.sciencedirect. com/science/article/pii/S0309174015000765>. Accessed: Nov. 12, 2018. doi: 10.1016/j.meatsci.2015.03.015.

LORENZO, J.M.; PATEIRO, M. Influence of fat content on physico-chemical and oxidative stability of foal liver pâté. Meat Science, v.95, p.330-335. 2013. Available from: $<$ https://www. sciencedirect.com/science/article/pii/S0309174013001678>. Accessed: Dec. 20, 2018. doi: 10.1016/j.meatsci.2013.04.045.

NASSU, R.T. et al. Oxidative stability of fermented goat meat sausage with different levels of natural antioxidant. Meat Science, v.63, p.43-49, 2003. Available from: <https://www.sciencedirect. com/science/article/pii/S0309174002000517>. Accessed: dec. 15, 2018. doi: 10.1016/S0309-1740(02)00051-7.

NORMA PORTUGUESA. NP-ISO-8586-1: Análise sensorial. Guia geral para a selecção, treino e controlo dos provadores. Parte 1: Provadores qualificados. Instituto Português da Qualidade, Ministério da Economia e Inovação, Caparica, Portugal, 2001.

PAULOS, K. et al. Sensory Characterization and Consumer Preference Mapping of Fresh Sausages Manufactured with Goat and Sheep Meat. Journal of Food Science, v.80, n.7, p.S156873, 2015. Available from: <https://onlinelibrary.wiley.com/doi/ full/10.1111/1750-3841.12927>. Accessed: Dec. 15, 2018. doi: $10.1111 / 1750-3841.12927$.

RODRIGUES, S.; TEIXEIRA, A. Effect of sex and carcass weight on sensory quality of goat meat of Cabrito Transmontano. Journal of Animal Science, v.87, p.711-5, 2009. Available from: $<$ https:// academic.oup.com/jas/article/87/2/711/4731247>. Accessed: Dec. 20, 2018. doi: 10.2527/jas.2007-0792

RODRIGUES, S.; TEIXEIRA, A. Consumers' preferences for meat of Cabrito Transmontano. Effects of sex and carcass weight. Spanish Journal of Agricultural Research, v.8, n.4, p.936945, 2010. Available from: <http://revistas.inia.es/index.php/ sjar/article/view/1388>. Accessed: Dec. 20, 2018. doi: 10.5424/ sjar/2010084-1388.

RODRIGUES, S.; TEIXEIRA, A. Use of generalized Procrustes analysis (GPA) to test the effects of sex and carcass weight on sensory quality evaluations of Terrincho lamb meat. Meat Science, v. 93, p. 485-488, 2013. Available from: <https://www. sciencedirect.com/science/article/pii/S0309174012003592>. Accessed: Nov. 12, 2018. doi: 0.1016/j.meatsci.2012.10.011.

STERLING, R.; JONES, A. World Food: Spain. Lonely Publications Lda, Victoria, Australia, pp. 304, 2000.

VIANA, F.R. et al. Quality of ham pâté containing bovine globin and plasma as fat replacers. Meat Science, v.70, p.153-160, 2005. Available from: <https://www.sciencedirect.com/science/ article/pii/S0309174005000252>. Accessed: Dec. 15, 2018. doi: 10.1016/j.meatsci.2004.12.013.

WEBB, E.C. et al. Goat meat quality. Small Ruminant Research, v.60, p.153-166, 2005. Available from: <https://www.sciencedirect. com/science/article/pii/S0921448805002269?via\%3Dihub>. Accessed: Dec. 15, 2018. doi: 10.1016/j.smallrumres.2005.06.009. 